\section{JURNAL EKONOMI EFEKTIF}

ISSN : $2622-8882$, E-ISSN : 2622-9935

Jurnal Ekonomi Efektif, Vol. 3, No. 3, April 2021 @Prodi Manajemen Fakultas Ekonomi Universitas Pamulang

\title{
PENGARUH CAPITAL ADEQUACY RATIO DAN BOPO RATIO TERHADAP RETURN ON ASSET PADA PT. BANK MUAMALAT INDONESIA, TBK PERIODE 2010-2019
}

\author{
Asep Muhammad Lutfi ${ }^{*}$, Heri Erlangga ${ }^{2}$, Nurjaya ${ }^{3}$, Sidik Priadana $^{4}$, \\ Denny Aditya Dwiwarman 5
Universitas Pamulang ${ }^{1}$, Tangerang Selatan, Banten, Indonesia
Universitas Pasundan ${ }^{2.4}$, Bandung, Jawa Barat, Indonesia
Universitas Suryakancana $^{3}$, Cianjur, Jawa Barat, Indonesia
Universitas Putra Indonesia ${ }^{5}$, Cianjur, Jawa Barat, Indonesia dosen02469@unpam.ac.id*

Manuskrip: Mar-2021 Ditinjau: Mar-2021; Diterima: Mar-2021; Online: Apr-2021; Diterbitkan: Apr-2021

\begin{abstract}
ABSTRAK
Penelitian ini bertujuan untuk mengetahui Pengaruh Capital Adequacy Ratio dan BOPO Ratio Terhadap Return On Asset Pada PT. Bank Muamalat Indonesia, Tbk. Metode yang digunakan adalah explanatory research. Teknik analisis menggunakan analisis statistik dengan pengujian regresi, korelasi, determinasi dan uji hipotesis. Hasil penelitian ini Capital Adequacy Ratio berpengaruh signifikan terhadap Return On Asset sebesar 45,5\%, uji hipotesis diperoleh t hitung > t tabel atau $(2,583>2,306)$. BOPO Ratio berpengaruh signifikan terhadap Return On Asset sebesar 47,6\%, uji hipotesis diperoleh $t$ hitung $>t$ tabel atau $(2,698>2,306)$. Capital Adequacy Ratio dan BOPO Ratio secara simultan berpengaruh signifikan terhadap Return On Asset diperoleh persamaan regresi $\mathrm{Y}=-0,158+0,013 \mathrm{X} 1+0,035 \mathrm{X} 2$ dan nilai determinasi sebesar 66,1\%, uji hipotesis diperoleh nilai $\mathrm{F}$ hitung $>\mathrm{F}$ tabel atau $(6,823>4,350)$.
\end{abstract}

\section{Kata Kunci: Capital Adequacy Ratio, BOPO Ratio, Return On Asset.}

\section{ABSTRACT}

This study aims to determine the effect of Capital Adequacy Ratio and BOPO Ratio on Return On Assets at PT. Bank Muamalat Indonesia, Tbk. The method used is explanatory research. The analysis technique uses statistical analysis with regression testing, correlation, determination and hypothesis testing. The results of this study Capital Adequacy Ratio has a significant effect on Return on Assets by 45.5\%, hypothesis testing obtained t count> t table or (2.583 > 2.306). BOPO Ratio has a significant effect on Return On Assets by 47.6\%, hypothesis testing is obtained t count $>$ t table or (2,698>2,306). Capital Adequacy Ratio and BOPO Ratio simultaneously have a significant effect on Return On Assets, the regression equation is $Y=-$ $0.158+0.013 X 1+0.035 X 2$ and a determination value of $66.1 \%$, hypothesis testing obtained $F$ value $>F$ table or $(6.823>4,350)$.

Keywords: Capital Adequacy Ratio, BOPO Ratio, Return On Assets. 


\section{PENDAHULUAN}

\section{A. Latar Belakang}

Pada dekade tahun 1980-an Indonesia pernah mengalami resesi dimana kondisi tersebut juga berimbas pada industri perbankan seperti (1) tingkat kepercayaan masyarakat dalam dan luar negeri terhadap perbankan di Indonesia menurun drastis; (2) sebagian besar bank dalam keadaan tidak sehat; (3) terjadi „,negative spread ; (4) munculnya penggunaan peraturan perundangan yang baru; dan (5) jumlah bank menurun (Muhamad, 2005). Sehubungan dengan kondisi-kondisi yang dialami oleh perbankan tersebut, maka muncul suatu sistem perbankan alternatif yaitu bank syariah. Sistem bank syariah ini dapat membantu memulihkan perekonomian dengan sistem kemitraan dan kebersamaan (sharing) dalam profit dan risk sehingga kegiatan perekonomian akan lebih adil dan transparan. Untuk itu, dibentuklah UU No 10 tahun 1998 yang memberikan landasan kelembagaan dan operasional perbankan syariah secara komprehensif.

Kegiatan operasional bank syariah di Indonesia dimulai pada tahun 1992 melalui pendirian PT. Bank Muamalat Indonesia, Tbk yang dinobatkan sebagai bank umum syariah pertama di Indonesia. Dalam perkembangannya sejak BMI terbentuk, industry perbankan syariah di Indonesia semakin berkembang. Pada awalnya bank syariah di Indonesia hanya tercatat sebanyak tiga buah, namun kini pertumbuhannya semakin meningkat. Indikator dari kinerja suatu perusahaan salah satunya adalah profitabilitas. Profitabilitas merupakan kemampuan manajemen dalam menghasilkan laba. Salah satu proksi yang tepat untuk mengukur profitabilitas suatu bank adalah dengan melihat besar kecilnya Return On Asset (ROA), ini menunjukan kemampuan bank dalam menghasilkan income dari pengelolaan aset yang dimilikinya.

Kinerja bank syariah dapat dinilai melalui berbagai macam variabel yang diambil dari laporan keuangan bank syariah. Laporan keuangan tersebut menghasilkan sejumlah rasio keuangan yang dapat membantu para pemakai laporan keuangan dalam menilai kinerja bank syariah.

Tabel 1. Perkambang CAR, BOPO dan ROA PT. PT. Bank Muamalat, Tbk Periode 2010-2019.

\begin{tabular}{|c|c|c|c|}
\hline Tahun & CAR (\%) & BOPO (\%) & ROA (\%) \\
\hline 2010 & 32.22 & 57.42 & 2.27 \\
\hline 2011 & 32.81 & 82.64 & 2.78 \\
\hline 2012 & 38.15 & 83.64 & 3.42 \\
\hline 2013 & 34.09 & 81.38 & 3.37 \\
\hline 2014 & 48.81 & 75.68 & 3.58 \\
\hline 2015 & 42.81 & 69.73 & 2.68 \\
\hline 2016 & 46.62 & 87.66 & 2.98 \\
\hline 2017 & 44.64 & 92.24 & 3.88 \\
\hline 2018 & 96.99 & 85.52 & 3.45 \\
\hline 2019 & 99.55 & 88.77 & 4.86 \\
\hline Rata-rata & 51.67 & 80.47 & 3.33 \\
\hline
\end{tabular}

Berdasarkan data pada tabel di atas, Laporan Tahunan PT. Bank MuamalatIndonesia menunjukkan terjadinya fluktuasi pada rasio-rasio keuangan antara lain, adanya kenaikan pada CAR secara rata-rata pertahun sebesar 51,67\%. Meskipun beberapa tahun mengalami perubahan namun nilai CAR masih tergolong baik dimana nilai tersebut berkaitan dengan faktor permodalan bank untuk mengukur kecukupan modal yang dimiliki bank untuk menanggung aktiva yang berisiko. Apabila modal yang dimiliki oleh bank tersebut mampu menanggung risiko-risiko yang 
tidak dapat dihindari, maka bank dapat mengelola seluruh kegiatannya secara efisien, sehingga kekayaan yang dimiliki bank diharapkan semakin meningkat dan begitu pula sebaliknya (Pramudhito, 2014). Maka, dapat disimpulkan hubungan CAR dan ROA adalah positif. Semakin besar rasio CAR maka semakin baik ROA pada suatu Bank.

Dilihat pada BOPO juga mengalami ketidakstabilan setiap tahunnya dimana sempat megalami penurunan dari tahun 2014 sampai dengan tahun 2015 yang cukup baik namun di tahun 2016 mengalami kenaikan. Secara rata-rata mencapai 80,47 per tahun. Rasio BOPO ini memiliki fungsi untuk mengukur tingkat efisiensi dan kemampuan bank dalam melakukan kegiatan operasinya. Jika rasio ini rendah maka kinerja bank yang bersangkutan menunjukan tingkat efisiensi yang tinggi pada perusahaan (Riyadi, 2006).

Dari ke dua variabel di atas mempengaruhi fluktuasi nilai ROA, pencapai nilai laba terendah dialami tahun 2010 yang hanya mampu memperoleh $2,27 \%$ dan nilai laba tertinggi dicapai tahun 2019 yang mampu mencapai 4,86\%. Dari 10 tahun terakhir ratarata dicapai 3,33\% per tahun. Tingkat efisiensi bank dalam menjalankan operasinya berpengaruh terhadap tingkat pendapatan yang dihasilkan oleh bank.

Dari fenomena yang diungkapkan di atas maka peneliti tertarik untuk melakukan penelitian tentang profitabilitas perbankan yaitu Return On Asset (ROA). Penelitian ini menggunakan variabel dependen ROA dan CAR, BOPO sebagai variable independen, dengan judul "Pengaruh Capital Adequacy Ratio Dan BOPO Ratio Terhadap Return On Asset Pada PT. Bank Muamalat, Tbk".

\section{B. Rumusan Masalah}

1. Adakah pengaruh antara Capital Adequacy Ratio terhadap Return On Asset pada PT. Bank Muamalat Indonesia, Tbk?.

2. Adakah pengaruh antara BOPO Ratio terhadap Return On Asset pada PT. Bank Muamalat Indonesia, Tbk ?.

3. Adakah pengaruh secara simultan antara Capital Adequacy Ratio dan BOPO Ratio terhadap Return On Asset pada PT. Bank Muamalat Indonesia, Tbk?.

\section{Tujuan Penelitian}

1. Untuk mengetahui pengaruh antara Capital Adequacy Ratio terhadap Return On Asset pada PT. Bank Muamalat Indonesia, Tbk.

2. Untuk mengetahui pengaruh antara BOPO Ratio terhadap Return On Asset pada PT. Bank Muamalat Indonesia, Tbk.

3. Untuk mengetahui pengaruh secara simultan antara Capital Adequacy Ratio dan BOPO Ratio terhadap Return On Asset pada PT. Bank Muamalat Indonesia, Tbk.

\section{METODE PENELITIAN}

\section{Populasi}

Populasi dalam penelitian ini berdasar laporan keuangan selama 10 tahun PT. Bank Muamalat Indonesia, Tbk

\section{Sampel}

Teknik pengambilan sampling dalam penelitian ini adalah samplel jenuh, dimana semua anggota populasi dijadikan sebagai sampel. Dengan demikian sampel dalam penelitian ini laporan keuangan selama 10 tahun.

\section{Jenis Penelitian}

Jenis penelitian yang dipakai adalah asosiatif, dimana tujuannya adalah untuk mengetahui mencari keterhubungan antar variabel independen terhadap variabel 
dependen

\section{Metode Analisis Data}

Dalam menganalisis data digunakan uji asumsi klasik, regresi, koefisien korelasi, koefisien determinasi dan uji hipotesis baik parsial maupun simultan.

\section{HASIL PENELITIAN DAN PEMBAHASAN}

\section{Analisis Deskriptif}

Pada pengujian ini digunakan untuk mengetahui besarnya persentase minimum dan maksimum, persentase rata-rata dan standar deviasi dari masing-masing variabel. Adapun hasilnya sebagai berikut:

Tabel 1. Hasil Analisis Descriptive Statistics

\section{Descriptive Statistics}

\begin{tabular}{|l|r|r|r|r|r} 
& N & \multicolumn{1}{c|}{ Minimum } & Maximum & \multicolumn{1}{c}{ Mean } & \multicolumn{1}{c}{ Std. Deviation } \\
\hline CAR $(\mathrm{X} 1)$ & 10 & 32.22 & 99.55 & 51.6690 & 25.24073 \\
\hline BOPO (X2) & 10 & 57.42 & 92.24 & 80.4680 & 10.38055 \\
\hline ROA (Y) & 10 & 2.27 & 4.86 & 3.3270 & .72273 \\
\hline Valid N (listwise) & 10 & & & & \\
\hline
\end{tabular}

Capital Adequacy Ratio diperoleh nilai minimum sebesar 32,22\% dan nilai maximum 99,55\% dengan rata-rata sebesar 51,66\% dengan standar deviasi 25,24\%.

BOPO Ratio diperoleh nilai minimum sebesar 57,42\% dan nilai maximum 92,24\% dengan nilai rata-rata sebesar $80,46 \%$ dengan standar deviasi $10,380 \%$.

Return On Asset diperoleh nilai minimum sebesar 2,27\% dan nilai maximum $4,86 \%$ dengan rata-rata sebesar 3,32\% dengan standar deviasi $0,722 \%$.

\section{Analisis Verifikatif.}

Pada analisis ini dimaksudkan untuk mengetahui pengaruh variabel independen terhadap variabel dependen. Adapun hasil pengujian sebagai berikut:

\section{a. Analisis Regresi Linier Berganda}

Uji regresi ini dimaksudkan untuk mengetahui perubahan variabel dependen jika variabel independen mengalami perubahan. Adapun hasil pengujiannya sebagai berikut:

Tabel 2. Hasil Pengujian Regresi Liner Berganda

\begin{tabular}{|c|c|c|c|c|c|c|}
\hline \multirow{3}{*}{\multicolumn{2}{|c|}{ Model }} & \multicolumn{3}{|c|}{ Coefficients $^{a}$} & \multirow[b]{3}{*}{$t$} & \multirow[b]{3}{*}{ Sig. } \\
\hline & & \multicolumn{2}{|c|}{$\begin{array}{c}\text { Unstandardized } \\
\text { Coefficients }\end{array}$} & \multirow{2}{*}{$\begin{array}{c}\text { Standardized } \\
\text { Coefficients } \\
\text { Beta } \\
\end{array}$} & & \\
\hline & & $\mathrm{B}$ & Std. Error & & & \\
\hline 1 & (Constant) & -.158 & 1.258 & & -.125 & .904 \\
\hline & CAR (X1) & .013 & .007 & .471 & 1.952 & .092 \\
\hline & BOPO (X2) & .035 & .017 & .498 & 2.064 & .078 \\
\hline
\end{tabular}

a. Dependent Variable: ROA (Y)

Berdasarkan hasil pengujian pada tabel di atas, diperoleh persamaan regresi $\mathrm{Y}$ $=-0,158+0,013 \mathrm{X} 1+0,035 \mathrm{X} 2$. Dari persamaan tersebut dijelaskan sebagai berikut:

1) Konstanta sebesar -0,158 diartikan jika Capital Adequacy Ratio dan BOPO Ratio tidak ada, maka telah terdapat nilai Return On Asset sebesar -0,158 point.

2) Koefisien regresi Capital Adequacy Ratio sebesar 0,013, angka ini positif artinya setiap ada peningkatan Capital Adequacy Ratio sebesar 0,013 maka Return On Asset juga akan mengalami peningkatan sebesar 0,013 point.

3) Koefisien regresi $B O P O$ Ratio sebesar 0,035, angka ini positif artinya setiap ada peningkatan BOPO Ratio sebesar 0,035 maka Return On Asset juga akan mengalami peningkatan sebesar 0,035 point. 


\section{b. Analisis Koefisien Korelasi}

Analisis koefisien korelasi dimaksudkan untuk mengetahui tingkt kekuatan hubungan dari variabel independen terhadap variabel dependen baik secara parsial maupun simultan. Adapun hasil pengujian sebagai berikut:

Tabel 3. Hasil Pengujian Koefisien Korelasi Capital Adequacy Ratio Terhadap Return On Asset.

Correlations $^{\text {b }}$

\begin{tabular}{llr|r} 
& & CAR $(X 1)$ & ROA $(Y)$ \\
\hline CAR $(X 1)$ & Pearson Correlation & 1 & $.674^{*}$ \\
\cline { 2 - 4 } & Sig. (2-tailed) & & .032 \\
\hline ROA (Y) & Pearson Correlation & $.674^{*}$ & 1 \\
\cline { 2 - 4 } & Sig. (2-tailed) & .032 & \\
\hline
\end{tabular}

${ }^{\star}$. Correlation is significant at the 0.05 level (2-tailed).

b. Listwise $\mathrm{N}=10$

Berdasarkan hasil pengujian diperoleh nilai korelasi sebesar 0,674 artinya Capital Adequacy Ratio memiliki hubungan yang kuat terhadap Return On Asset.

Tabel 4. Hasil Pengujian Koefisien Korelasi BOPO Ratio Terhadap Return On Asset.

Correlations $^{b}$

\begin{tabular}{llr|r} 
& & BOPO (X2) & \multicolumn{2}{r}{ ROA (Y) } \\
\hline BOPO (X2) & Pearson Correlation & 1 & $.690^{*}$ \\
\cline { 2 - 4 } & Sig. (2-tailed) & & .027 \\
\hline ROA (Y) & Pearson Correlation & $.690^{*}$ & 1 \\
\cline { 2 - 4 } & Sig. (2-tailed) & .027 & \\
\hline
\end{tabular}

*. Correlation is significant at the 0.05 level (2-tailed).

b. Listwise $\mathrm{N}=10$

Berdasarkan hasil pengujian diperoleh nilai korelasi sebesar 0,690 artinya BOPO Ratio memiliki hubungan yang kuat terhadap Return On Asset.

Tabel 5. Hasil Pengujian Koefisien Korelasi Capital Adequacy Ratio dan BOPO Ratio secara simultan Terhadap Return On Asset.

\begin{tabular}{|c|c|c|c|c|}
\hline \multicolumn{5}{|c|}{ Model Summary } \\
\hline Model & $\mathrm{R}$ & R Square & $\begin{array}{l}\text { Adjusted R } \\
\text { Square }\end{array}$ & $\begin{array}{l}\text { Std. Error of the } \\
\text { Estimate }\end{array}$ \\
\hline 1 & $.813^{a}$ & .661 & .564 & .47717 \\
\hline
\end{tabular}

a. Predictors: (Constant), BOPO (X2), CAR (X1)

Berdasarkan hasil pengujian diperoleh nilai korelasi sebesar 0,813 artinya Capital Adequacy Ratio dan BOPO Ratio secara simultan memiliki hubungan yang sangat kuat terhadap Return On Asset.

\section{c. Analisis Koefisien Determinasi}

Analisis koefisien determinasi dimaksudkan untuk mengetahui besarnya persentase pengaruh dari variabel independen terhadap variabel dependen baik secara parsial maupun simultan. Adapun hasil pengujian sebagai berikut:

Tabel 6. Hasil Pengujian Koefisien Determinasi Capital Adequacy Ratio Terhadap

Return On Asset.

\section{Model Summary}

\begin{tabular}{|c|c|c|c|c|}
\hline & & 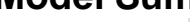 & & \\
\hline Model & $\mathrm{R}$ & R Square & $\begin{array}{l}\text { Adjusted R } \\
\text { Square }\end{array}$ & $\begin{array}{c}\text { Std. Error of the } \\
\text { Estimate }\end{array}$ \\
\hline 1 & $.674^{a}$ & .455 & .387 & .56606 \\
\hline
\end{tabular}

a. Predictors: (Constant), CAR (X1)

Berdasarkan hasil pengujian diperoleh nilai determinasi sebesar 0,455 artinya Capital Adequacy Ratio memiliki kontribusi pengaruh sebesar 45,5\% terhadap Return On Asset. 
Tabel 7. Hasil Pengujian Koefisien Determinasi BOPO Ratio Terhadap Return On Asset.

Model Summary

\begin{tabular}{|c|c|c|c|c|}
\hline Model & $\mathrm{R}$ & R Square & $\begin{array}{l}\text { Adjusted R } \\
\text { Square }\end{array}$ & $\begin{array}{c}\text { Std. Error of the } \\
\text { Estimate }\end{array}$ \\
\hline 1 & $.690^{\mathrm{a}}$ & .476 & .411 & .55466 \\
\hline
\end{tabular}

a. Predictors: (Constant), BOPO (X2)

Berdasarkan hasil pengujian diperoleh nilai determinasi sebesar 0,476 artinya BOPO Ratio memiliki kontribusi pengaruh sebesar 47,6\% terhadap Return On Asset. Tabel 8. Hasil Pengujian Koefisien Determinasi Capital Adequacy Ratio dan BOPO Ratio Terhadap Return On Asset. Model Summary

\begin{tabular}{l|c|c|c|c} 
Model & $\mathrm{R}$ & $\mathrm{R}$ Square & $\begin{array}{c}\text { Adjusted R } \\
\text { Square }\end{array}$ & $\begin{array}{c}\text { Std. Error of the } \\
\text { Estimate }\end{array}$ \\
\hline 1 & $.813^{\mathrm{a}}$ & .661 & .564 & .47717 \\
\hline a. Predictors: (Constant), BOPO (X2), CAR (X1) & &
\end{tabular}

Berdasarkan hasil pengujian diperoleh nilai determinasi sebesar 0,661 artinya Capital Adequacy Ratio dan BOPO Ratio secara simultan memiliki kontribusi pengaruh sebesar 66,1\% terhadap Return On Asset, sedangkan sisanya sebesar 33,9\% dipengaruhi faktor lain.

\section{d. Uji Hipotesis}

\section{Uji hipotesis Parsial (Uji t)}

Pengujian hipotesis dengan uji t digunakan untuk mengetahui hipotesis parsial mana yang diterima.

Tabel 9. Hasil Uji Hipotesis Capital Adequacy Ratio Terhadap Return On Asset.

\begin{tabular}{|c|c|c|c|c|c|c|}
\hline \multicolumn{7}{|c|}{ Coefficients ${ }^{a}$} \\
\hline \multirow{2}{*}{\multicolumn{2}{|c|}{ Model }} & \multicolumn{2}{|c|}{ Unstandardized Coefficients } & \multirow{2}{*}{$\begin{array}{l}\text { Standardized } \\
\text { Coefficients } \\
\text { Beta }\end{array}$} & \multirow[b]{2}{*}{$t$} & \multirow[b]{2}{*}{ Sig. } \\
\hline & & B & Std. Error & & & \\
\hline 1 & (Constant) & 2.329 & .426 & & 5.472 & .001 \\
\hline & CAR (X1) & .019 & .007 & .674 & 2.583 & .032 \\
\hline
\end{tabular}

a. Dependent Variable: ROA (Y)

Berdasarkan hasil pengujian pada tabel di atas, diperoleh nilai t hitung $>\mathrm{t}$ tabel atau $(2,583>2,306)$, dengan demikian terdapat pengaruh yang signifikan atara Capital Adequacy Ratio terhadap Return On Asset.

Tabel 10. Hasil Uji Hipotesis BOPO Ratio Terhadap Return On Asset.

\begin{tabular}{|c|c|c|c|c|c|c|}
\hline \multirow{2}{*}{\multicolumn{2}{|c|}{ Model }} & \multicolumn{2}{|c|}{$\begin{array}{l}\text { Unstandardized } \\
\text { Coefficients }\end{array}$} & \multirow{2}{*}{$\begin{array}{l}\text { Standardized } \\
\text { Coefficients } \\
\text { Beta }\end{array}$} & \multirow[b]{2}{*}{$\mathrm{t}$} & \multirow[b]{2}{*}{ Sig. } \\
\hline & & B & Std. Error & & & \\
\hline 1 & (Constant) & $\begin{array}{l}-.540 \\
\end{array}$ & 1.444 & & -.374 & .718 \\
\hline & BOPO (X2) & .048 & .018 & 690 & 2.698 & .027 \\
\hline
\end{tabular}

a. Dependent Variable: ROA $(\mathrm{Y})$

Berdasarkan hasil pengujian pada tabel di atas, diperoleh nilai t hitung $>\mathrm{t}$ tabel atau $(2,698>2,306)$, dengan demikian terdapat pengaruh yang signifikan atara BOPO Ratio terhadap Return On Asset.

\section{Uji Hipotesis Simultan (Uji F)}

Pengujian hipotesis dengan uji $\mathrm{F}$ digunakan untuk mengetahui hipotesis simultan yang mana yang diterima. 
Tabel 11. Hasil Uji Hipotesis Capital Adequacy Ratio dan BOPO Ratio Terhadap Return On Asset.

ANOVA $^{\mathrm{a}}$

\begin{tabular}{|c|c|c|c|c|c|c|}
\hline \multicolumn{7}{|c|}{ ANOVA $^{\mathrm{a}}$} \\
\hline \multicolumn{2}{|c|}{ Model } & Sum of Squares & $\mathrm{df}$ & $\begin{array}{l}\text { Mean } \\
\text { Square }\end{array}$ & $\mathrm{F}$ & Sig. \\
\hline \multirow[t]{3}{*}{1} & Regression & 3.107 & 2 & 1.554 & 6.823 & $.023^{b}$ \\
\hline & Residual & 1.594 & 7 & .228 & & \\
\hline & Total & 4.701 & 9 & & & \\
\hline
\end{tabular}

a. Dependent Variable: ROA (Y)

b. Predictors: (Constant), BOPO (X2), CAR (X1)

Berdasarkan hasil pengujian pada tabel di atas, diperoleh nilai $\mathrm{F}$ hitung $>\mathrm{F}$ tabel atau $(6,823>4,350)$, dengan demikian terdapat pengaruh yang signifikan atara Capital Adequacy Ratio dan BOPO Ratio terhadap Return On Asset.

\section{PEMBAHASAN HASIL PENELITIAN}

\section{Pengaruh Capital Adequacy Ratio Terhadap Return On Asset}

Capital Adequacy Ratio berpengaruh signifikan terhadap Return On Asset dengan korelasi sebesar 0,674 atau memiliki hubungan yang kuat dengan kontribusi pengaruh sebesar 45,5\%. Pengujian hipotesis diperoleh nilai $\mathrm{t}$ hitung $>\mathrm{t}$ tabel atau $(2,583>$ 2,306). Dengan demikian terdapat pengaruh signifikan antara Capital Adequacy Ratio terhadap Return On Asset.

\section{Pengaruh BOPO Ratio Terhadap Return On Asset}

BOPO Ratio berpengaruh signifikan terhadap Return On Asset dengan korelasi sebesar 0,690 atau memiliki hubungan yang kuat dengan kontribusi pengaruh sebesar 47,6\%. Pengujian hipotesis diperoleh nilai t hitung > t tabel atau $(2,698>2,306)$. Dengan demikian terdapat pengaruh signifikan antara BOPO Ratio terhadap Return On Asset.

\section{Pengaruh Capital Adequacy Ratio dan BOPO Ratio Terhadap Return On Asset}

Capital Adequacy Ratio dan BOPO Ratio berpengaruh signifikan terhadap Return On Asset dengan diperoleh persamaan regresi $\mathrm{Y}=-0,158+0,013 \mathrm{X} 1+0,035 \mathrm{X} 2$, nilai korelasi sebesar 0,813 atau memiliki hubungan yang sangat kuat dengan kontribusi pengaruh sebesar $66,1 \%$ sedangkan sisanya sebesar 33,9\% dipengaruhi faktor lain. Pengujian hipotesis diperoleh nilai $\mathrm{F}$ hitung $>\mathrm{F}$ tabel atau $(6,823>4,350)$. Dengan demikian terdapat pengaruh signifikan antara Capital Adequacy Ratio dan BOPO Ratio terhadap Return On Asset.

\section{KESIMPULAN DAN SARAN}

\section{Kesimpulan}

a. Capital Adequacy Ratio berpengaruh signifikan terhadap Return On Asset dengan kontribusi pengaruh sebesar 45,5\%. Uji hipotesis diperoleh nilai t hitung $>\mathrm{t}$ tabel atau $(2,583>2,306)$.

b. BOPO Ratio berpengaruh signifikan terhadap Return On Asset dengan kontribusi pengaruh sebesar 47,6\%. Uji hipotesis diperoleh nilai t hitung $>\mathrm{t}$ tabel atau $(2,698>$ 2,306).

c. Capital Adequacy Ratio dan BOPO Ratio berpengaruh signifikan terhadap Return On Asset dengan kontribusi pengaruh sebesar $66,1 \%$ sedangkan sisanya sebesar $33,9 \%$ dipengaruhi faktor lain. Uji hipotesis diperoleh nilai $\mathrm{F}$ hitung $>\mathrm{F}$ tabel atau $(6,823>$ 4,350). 


\section{Saran}

Berdasarkan hasil analisis dan kesimpulan penelitian ini, maka ada beberapa temuan-temuan yang kiranya dapat menjadi bahan saran bagi pihak- pihak terkait, adapun saran yang diberikan sebagai berikut:

a. Pihak manajemen bank agar lebih memperhatikan likuiditas dan menjaga keseimbangan modal perusahaan pada bank dan lebih meningkatkan perolehan CAR pada perusahaan dalam kegiatannya.

b. Tingkat BOPO pada PT Bank Muamalat Indonesia masih belum mencapai standar yang telah ditetapkan oleh Bank Indonesia yakni 85\%. Kiranya pihak perbankan perlu mempertimbangkan aspek Biaya Operasional yang dikeluarkan dan meningkatkan kembali Pendapatan yang masuk guna meminimalisir resiko suatu perusahaan perbankan.

c. Bagi peneliti selanjutnya disarankan untuk melakukan penelitian di luar variabel independen yang digunakan dalam penelitian ini ataupun mengkombinasikan salah satu vaiabel dalam penelitian ini dengan vaiabel lain diluar variabel dalam penelitian ini, agar dapat memperoleh hasil yang lebih bervariatif yang dapat menggambarkan hal-hal apa saja yang dapat berpengaruh terhadap Return On Assets.

\section{DAFTAR PUSTAKA}

Agus Harjito \& Martono, (2010) "Manajemen Keuangan" Yogyakarta: Penerbit Ekonisia. Agus Sartono. (2010). "Manajemen Keuangan Toeri dan Aplikasi", Edisi keempat, Yogyakarta: Penerbit BPFE.

Algifari. (2015). "Analisis Regresi untuk Bisnis dan Ekonomi”. Yogyakarta: BPFE.

Amelia, R. W., \& Sunarsi, D. (2020). Pengaruh Return On Asset Dan Return On Equity Terhadap Debt To Equity Ratio Pada PT. Kalbe Farma, TBK. Ad-Deenar: Jurnal Ekonomi dan Bisnis Islam, 4(01), 105-114.

Anjayani, N. S., Lutfi, A. M., Suhartono, A., Sari, W. I., \& Sunarsi, D. (2020). Pengaruh Perputaran Persediaan dan Rasio Perputaran Aktiva Terhadap Return on Invesment Pada PT Gudang Garam Tbk. TIN: Terapan Informatika Nusantara, 1(4), 171-176.

Arikunto, Suharsimi (2014). "Prosedur Penelitian Suatu Pendekatan Praktek". Jakarta: Rineka Cipta.

Bambang Riyanto, (2011). "Dasar-dasar Pembelanjaan Perusahaan". Edisi ke empat, BPFE Yogyakarta.

Fahmi, Irham (2012), "Pengantar Manajemen Keuangan" Cetakan pertama. Bandung: Penerbit Alfabeta.

Haque, M. G., Nurjaya, N.,Affandi, A., Erlangga, H., \& Sunarsi, D. (2021). Micro Financial Sharia Non-bank Strategic Analysis: a Study at BMT Beringharjo, Yogyakarta. Budapest International Research and Critics Institute (BIRCI-Journal): Humanities and Social Sciences, 4(2), 1677-1686.

Imam Ghozali (2017). "Aplikasi Analisis Multivariate Dengan Program SPSS". Edisi Kelima. Semarang: Badan Penerbit Undip.

Istijanto (2014) "Riset Sumber Daya Manusia". Jakarta: PT. Gramedia Pustaka

Jasmani, J. (2018). Pengaruh Kinerja Keuangan Terhadap Harga Saham (Analisis Pada Perusahaan Property dan Real Estate Yang Go Public di Bursa Efek Indonesia. Jurnal Akuntansi Indonesia, 12(2).

Jasmani, J. (2019). The Effect of Liquidity and Working Capital Turnover on Profitability at PT. Sumber Cipta Multiniaga, South Jakarta. PINISI Discretion Review, 3(1), 2938. 
Kasmir (2010), “Analisis Laporan keuangan”, penerbit raja grafindo persada, Jakarta

Kasmir, (2010). "Pengantar Manajemen Keuangan”, Edisi Pertama, Cetakan kedua, Jakarta: Penerbit Prenada Media.

Kasmir. (2012) "Pengantar Manajemen Keuangan”, Edisi Pertama, Cetakan kedua, Jakarta: Prenada Media.

Kharis, Ismu Fadli (2011). "Studi Mengenai Impulse Buying dalam Penjualan Online". Semarang : Skripsi Universitas Diponegoro

Lutfi, A. M. (2020). The Effect of Quick Ratio and Debt to Ratio Assets Against Return on Assets. JASa (Jurnal Akuntansi, Audit dan Sistem Informasi Akuntansi), 4(1), 23 30 .

Lutfi, A. M., Kusumawati, Y., Khoiriah, N., \& Suhartono, A. (2021, January). Effect of Management Performance on Financial Performance at PT. HM Sampoerna, TBK Period 2007-2019. In Proceeding The First International Conference on Government Education Management and Tourism (Vol. 1, No. 1, pp. 8-12).

Martono dan Agus Harjito, (2011). "Manajemen Keuangan”, Jakarta: Penerbit Ekonisia..

Munawir (2010), “Analisis Laporan Keuangan”, Edisi Ke Empat, Penerbit Liberty, Yogyakarta.

Noryani, Y. B. G., Sari, W. I., Rosini, I., Munadjat, B., Sunarsi, D., \& Mahnun Mas' adi, G. (2020). Did ISO 45001, ISO 22000, ISO 14001 and ISO 9001 Influence Financial Performance? Evidence from Indonesian Industries. PalArch's Journal of Archaeology of Egypt/Egyptology, 17(7), 6930-6950.

Pujiati, H., Sunarsi, D., Affandi, A., \& Anggraeni, N. (2021). Effect of ISO 9001: 2015 Quality Management Implementation in Education on School Performance. Journal of Contemporary Issues in Business and Government, 27(1), 1848-1855.

Santoso, Singgih (2015). "Menguasai Statistik Multivariat". Jakarta: PT Elex Media Komputindo.

Sartono, "Manajemen Keuangan Aplikasi Dan Teori", Edisi Keempat, BPFE, Yogyakarta, 2008.

Sawir, (2003). “Analisis Kinerja Keuangan dan Perencanaan Keuangan Perusahaan”, Cetakan ketiga, Jakarta: Penerbit PT. Gramedia Pustaka Utama.

Sugiyarso, G. dan F. Winarni, "Manajemen Keuangan (Pemahaman Laporan Keuangan, Pengelolaan Aktiva, Kewajiban dan Modal serta Pengukuran

Sugiyono (2017), "Metode Penelitian Administrasi : dilengkapi dengan Metode R \& D". Bandung: Alfabeta.

Suhartono, A., Jati, W., \& Sunarsi, D. (2019). Pengaruh Earning Per Share Dan Return On Asset Terhadap Harga Saham Pada PT. Bank Negara Indonesia Tbk Periode 20092018. Jurnal Manajemen, Bisnis dan Organisasi (JUMBO), 3(3), 182-194. 